\title{
Камалов А.К.
}

д.и.н., профессор, Университет «Туран», Республика Казахстан, г. Алматы, e-mail: abletk@mail.ru

\section{«ААТИНСКИЙ ПУТЬ» В ИНТЕААЕКТУААЬНОЙ ИСТОРИИ УЙГУРОВ СРЕАНЕЙ АЗИИ И КАЗАХСТАНА}

В статье рассматривается процесс разработки и введения уйгурской письменности на ^атинской основе в Средней Азии и Казахстане в конце 1920-х годов. На основе анализа информационных статей, опубликованных в 1920-1930-е годы в газете «Камбагалмар авази», в журналах и книгах на уйгурском языке, издававшихся в Алма-Ате и Ташкенте, автор восстанавливает основные этапы разработки матинской графики уйгурского языка и ее внеАрения в книгопечатание, использования в периодических изданиях, а также в образовательной и культурной сферах. Отмечается совпадении матинизации с кампанией по ликвидации безграмотности населения. Более позАний с Аругими советскими народами переход уйгурского языка от матиницы к киримлице (1947 г.) объясняется советской политикой в отношении соседнего Синьцзяна и подАержкой национально-освободительного Авижения уйгуров против Гоминдана.

Кмючевые слова: матинизация, уйгурский язык, алфавит, Казахстан, Средняя Азия.

\author{
Камалов А.К. \\ т.ғ.А., профессор, «Тұран» университеті, Қазақстан Республикасы, Алматы қ., \\ e-mail: abletk@mail.ru
}

\section{«Аатинский путь» в интеммектуамьной истории уйгуров СреАней Азии и Казахстана}

В статье рассматривается процесс разработки и введения уйгурской письменности на ^атинской основе в Средней Азии и Казахстане в конце 1920-х годов. На основе анализа информационных статей, опубликованных в 1920-1930-е годы в газете «Камбагамлар авази», в журналах и книгах на уйгурском языке, издававшихся в Амма-Ате и Ташкенте, автор восстанавливает основные этапы разработки латинской графики уйгурского языка и ее внедрения в книгопечатание, использования в периодических изданиях, а также в образовательной и культурной сферах. Отмечается совпадении матинизации с кампанией по ликвидации безграмотности населения. Более позАний с Аругими советскими народами переход уйгурского языка от матиницы к кириммице (1947 г.) объясняется советской политикой в отношении сосеАнего Синьцзяна и поААержкой национально-освободительного Авижения уйгуров против Гоминдана.

Ключевые слова: латинизация, уйгурский язык, алфавит, Казахстан, СреАняя Азия.

\section{Kamalov A.K. \\ Doctor of Historical Sciences, Professor, University "Turan”, Kazakhstan, Almaty, e-mail: abletk@mail.ru \\ «Latin Way» in the intellectual history of the Uighurs of Central Asia and Kazakstan}

The article examines the process of design and introduction of the Latin alphabet for the Uyghur language in Soviet Central Asia and Kazakhstan in the end of the 1920s. Based on analysis of the informational articles published in the 1920-1920s in the newspaper 'Kambaghallar avazi', in the Uyghur journals and books published in Alma-Ata and Tashkent, the author reconstructs main stages of working out of the Latin alphabet for the Uyghur language and its use in the publishing houses, in periodicals, as well as in educational and cultural spheres. He observes that latinization coincided with the campaign on liquidation of illiteracy of people. More later transfer of the Uyghur language from Latin to Cyrillic, in comparison with other Central Asian peoples, is linked to the Soviet policy towards neighboring Xinjiang and the support of national-liberation movement of the Uyghurs against the Guomindang.

Key words: latinization, Uyghur language, alphabet, Kazakhstan, Central Asia. 
Камалов А.К.

\section{Введение}

В Казахстане в 2025 г. в планируется переход казахского языка на латинскую графику. В связи с этим возникает вопрос о латинизации графики других тюркоязычных этносов страны, близких к казахам по языку и культуре и использующих кириллицу в сфере образования и культуры, в средствах массовой информации и издательском деле. К ним относятся уйгуры, которые в советское время прошли те же этапы реформирования письменности от арабской графики к латинице, а затем от латинского письма - к кириллице. Осмысление опыта использования уйгурами латинского алфавита в 1930-1940-х гг. становится важным на этапе новой латинизации письменности уйгурского языка (Ғожәмбәрди, 1989).

\section{Основная часть}

Прежде чем говорить о латинизации языка советских уйгуров, нужно отметить, что уйгуры относятся к народам с богатой письменной культурой. В историческом прошлом они и их предки в Восточном Туркестане не только использовали разные системы письма, но и сами были создателями алфавита, который вошел в историю как «уйгурский» (Малов, 1951: 105-106; Наджип, 1960: 7). Уйгурское письмо, как и тюркское руническое письмо, которым пользовались уйгуры в VIII-IX вв., было создано на основе согдийского алфавита. Уйгурское письмо стало средством общения во всем тюркском мире в среднике века и стало основой, на которой были в последующем разработаны монгольское и маньчжурское письма. Кроме рунического и уйгурского курсивного письма, уйгурские тексты были написаны и на других письменностях Центральной Азии. С приходом ислама все эти письма уступили место арабской графике, которая уйгурами и другими тюрками использовалась в ее персидском варианте.

Падение Российской империи в 1917 г. и приход к власти большевиков ознаменовали собой начало новой эпохи модернизации всех сфер общественной жизни народов азиатской части бывшей Российской империи. Уже в первые годы после создания СССР представители уйгурской интеллигенции начали работать над внесением изменений в арабскую графику, которые бы соответствовали специфике уйгурской фонетики. В Москве над адаптацией арабской графики к звуковому составу уйгурского языка работали студенты Коммунистического университета трудящихся Востока. В результате этой работы в 1926 г. вышла в свет публикация Аб- дулхая Мухаммади «Пути уйгурского письма» (уйг. уйзурчд йезиқ йоллири), в которой автор обсуждал вопросы орфографии, предлагал новую систему диакратических знаков и призывал очищению уйгурской лексики от арабо-персидских заимствований. Свои стандарты уйгурского языка предлагал и Кадыр Хаджи, выходец из Кашгара, участвовавший в известных спорах об уйгурской нации в 1920-1930-х годах. Он начала издание газеты в Ташкенте, которому дал название закрытого ранее в Киргизии издания на уйгурском языке - «Қутулуш» (Освобождение).

В самый разгар реформирования арабской графики, в 1929 г., советское правительство объявило о переходе языков народов Средней Азии и Казахстана на латинскую графику. С чем было связано решение о латинизации? Зачастую политику латинизации объясняют подражанием Ататюрку, который перевел турецкий язык на латинское письмо в 1928 г. Однако такое объяснение является неверным, поскольку движение за использование латиницы вместо арабского алфавита началось в России еще в 1921 г., а азербайджанцы приняли латинскую графику 1925 г. На самом деле, политика латинизации в Советском Союзе была начата под влиянием идеи о мировой революции, согласно которой в ближайшем будущем рабочий класс во всем мире должен был уничтожить старый мир и построить коммунистическое общество. В представлениях революционеров арабская графика была символом отсталого мусульманского общества. Именно с ней ассоциировалась массовая безграмотность мусульманских народов и пагубное влияние религии на сознание людей. Культурная революция требовала новой символики, которой и стала латинская графика, использовавшаяся во многих индустриально развитых странах мира (Ерзин, 1988: 129).

Для начала массовой кампании по латинизации в Советском Союзе большое значение имел Первый тюркологический съезд, состоявшийся в Баку в 1926 г., в котором приняли участие представители разных тюркских народов и ученые из Москвы и Ленинграда. На нем было принято решение о желательности распространения опыта Азербайджана по латинизации в других республиках и автономных областях страны. Для руководства латинизацией был создан Всесоюзный центральный комитет нового тюркского алфавита во главе с азербайджанским деятелем Агамалы оглы.

Частью кампании по латинизации стала разработка новых алфавитов для малых народов 
Средней Азии и Казахстана, в число которых входили уйгуры, татары и дунгане. В уйгурской публицистике 1920-х годов эта кампания получила название «уйгурский путь» (уйг. латинчилиқ йоли).

Разработка латинского алфавита для уйгурского языка обнажила разногласия, существовавшие среди представителей двух групп советских уйгуров - таранчей Семиречья и кашгарцев Ферганской долины. Необходимость перехода на латинскую графику понимала вся уйгурская интеллигенция, независимо от региона проживания. О значении «латинского пути» для уйгуров писал А. Мухаммадий: «Два пути: или идти с 27 арабскими буквами, и всю жизнь не освободишься от проблем, споров и беспокойств, или бросай арабские буквы, и освободись от споров, проблем, беспокойств. Нам, конечно, нужно выбрать второй путь» (Садвакасов, 2009: 301).

Инициативу по созданию алфавита взяла в руки уйгурская интеллигенция Узбекистана, которая созвала 29 апреля 1928 г. в Самарканде Первую конференцию языковедов по уйгурскому языку и орфографии. На конференцию были приглашены 20 человек, представлявших Узбекистан, Казахстан, Кыргызстан и Туркменистан, однако в силу разных причин участвовали только 14 человек (Муһәммәди, 1928: 2-3). Участники конференции, которая проходила под руководством Һусән Карими, отвергли проекты латиницы, предложенные Б. Насирий из Кыргызстана (из 28 букв) и Л. Әнсәри из Казахстана (из 33 букв) и утвердили свой вариант алфавита из 31 буквы (с последующим добавлением буквы «f»), составленный А. Мухаммади (Ерзин, 1988: 22).

Важным решением самаркандской конференции было признание того, что уйгуры Средней Азии и Восточного Туркестана имеют единый язык, в котором существуют диалекты с небольшими фонетическими и местными различиями. Формирование норм уйгурского литературного языка было признано неотложной задачей языковедов, в связи с чем было принято решение о единообразии в написании слов, по-разному звучавших в диалектах. Например, предпочтительными признаны были такие формы слов, как «өтүк» (сапог), «отун» (дрова), «болуб» (будучи), «хотун» (жена), вместо «өтәк», «отан», «болаб», «хотан». Наконец, для реализации решений конференции в пределах Узбекистана была создана уйгурская научная секция во главе c h.Кәрими и его заместителем писателем и просветителем А. Мухаммади (Муһәммәди, 1929: 3).
Латинский алфавит, принятый в Самарканде, был в последующем утвержден Первой конференцией по введению нового алфавита в Казахстане, состоявшейся 9-13 декабря 1928 г. в столице Казахской АССР - г. Кызыл-Орде. Эта конференция рассмотрела вопросы, связанные с переходом казахского языка на латинскую графику, а также вопросы казахской орфографии и установила сроки поэтапного введения нового алфавита. Одним из вопросов повестки дня конференции был вопрос о переходе на латиницу малых народов Казахстана (Муһәммәди, 1929: 3).

План перехода на латиницу включал следующие этапы: 1) прием документов всеми учреждениями и организациями с 1 октября 1929 г., 2) издание всей литературы на латинице с 1 октября 1930 г., 3) использование документации на арабской графики до 1 октября 1931 г., после которого прекращается использование арабского письма, 4) полный переход школ Казахстана на обучение на основе латинской графики в 19311932 учебном году (Муһәммәди, 1929: 3).

Большая роль по внедрению латинского алфавита и разработке орфографических норм уйгурского языка принадлежала упомянутому выше Абдулхаю Мухаммади, который знакомил читателей уйгурских газет и журналов с деятельностью конференций по новому алфавиту и предлагал меры по его внедрению. В числе последних он называл, в частности, открытие на местах кружков и ячеек по изучению алфавита, организацию соревнований между селами по знанию латиницы, активизацию работы школьных учителей по распространении нового алфавита. Большую роль в распространении латинского алфавита должны были сыграть уйгурские коммунисты и комсомольцы.

Уйгурские средства массовой информации внесли свой вклад в пропаганду перехода на латиницу. Так, в газете «Кәмбағәлләр авази» в 1929 г. была открыта рубрика «Новый уйгурский алфавит» (уйг. уйхур йеңъи әлипбәси). В ней регулярно печатался латинский алфавит, а также давались небольшие информационные тексты латинским шрифтом для приучения читателей к латинской графике. В одном из номеров газеты от 10 апреля 1929 г. в этой рубрике были даны два текста на латинице, затрагивающие вопросы внедрения нового алфавита. Первый текст носил информационный характер и гласил: «В этом году в начальной школе села Шункар Яркенда начали обучение латинской письменности. Сейчас дети научились писать на ней» (уйг.: Йәркәтниң Шуңқар йезисида бу жили оқуш 
залида биринчи балдақ мәктәпидә латинчә үгүнгүли башлиған иди. Һазир балилар оқуп йазидиған болуп қалди) (Кәмбәғәлләр авази, №19, 1929: 4). Второй текст был составлен в виде кратких вопросов и ответов об особенностях латинской графики. На вопрос, когда же газета будет размещать уроки латинского, редакция сослалась на нехватку латинских шрифтов в типографии (Кәмбәғәлләр авази, №30, 1929: 4).

10 июня 1929 г. газета «Кәмбәғәлләр авази» дала две другие информации, касающиеся латиницы:

(1) «Стали грамотными. Во втором классе школы села Малый Дихан Яркенда в этому году начались уроки по новому алфавиту. Сейчас дети научились читать и писать на новом алфавите. Среди них восемь девочек».

(2) «Организация по обучению новому алфавиту. В уйгурской школе Яркенда создана организация по изучению новому алфавиту. Собираются один раз в неделю. В ней 38 членов. Проводят доклады по новому алфавиту. По одному часу уделяется обучению новому алфавиту» Кәмбәғәлләр авази, №30, 1929: 4).

Для пропаганды нового алфавита газета «Кәмбағәлләр авази» размещала также отдельные стихи уйгурских поэтов на латинской графике. Так, латинской графикой было опубликовано стихотворение «Гүлләр теридуқ» (Мы собирали цветы) Омара Мухаммади. Этот случай публикации стихотворного произведения на латинском в арабографичной газете приводится академиком Г.С. Садвакасовым как образец применения латиницы в 1930-е годы (Садвакасов, 2009: 310-311).

Большое внимание ознакомлению читателей с латинской графикой уделяли и уйгурские издания Ташкента. Так, журнал уйгурских студентов Среднеазиатского государственного университета «Инқилабчи шәриқ» (Революционный Восток) в номерах от 1929 г. не только знакомил читателей с латинским алфавитом, но давал отдельные материалы на новой графике (Инқилабчи шәрқ, 1929: 24-25).

Переход на новый алфавит обнажил давнюю проблему отсутствия единых норм правописания в уйгурском языке. Создание стандартов уйгурского литературного языка стало главным вопросом Второй конференции по уйгурскому языку и орфографии, состоявшейся 13-18 мая 1930 г. в Алма-Ате. На конференцию были приглашены известные тюркологи Александр Самойлович и Сергей Малов. Благодаря С.Е. Малову открытая на конференции дискуссия о диалектах уйгурс- кого языка вышла за рамки обсуждения особенностей таранчинского и кашгарского диалектов. С. Малов поддержал орфографию газеты «Кәмбәғәлләр авази» и рекомендовал газете «Қутулуш», которая издавалась в Ташкенте, следовать семиреченским стандартам. Таким образом, илийско-семиреченский диалект был признан основой литературного языка советских уйгуров.

В недавно вышедшей книге «Уйгурская нация. Реформы и революции на русско-китайской границе» (2016) Дэвид Брофи рассматривает Вторую конференцию по уйгурскому языку и орфографии как важное событие в достижении компромисса в выработке единых стандартов уйгурского языка, когда был поставлен конец спорам о различиях в языке илийских таранчей и ферганских кашгарцев (Brophy, 2016: 226-231).

Советские уйгуры использовали уйгурскую графику дольше, чем остальные родственные народы Средней Азии и Казахстана, большинство из которых перешли на кириллицу в 1940 г. Вопросом перевода уйгурского языка на русскую графику правительство Казахской ССР приступило только в 1946 г. Проект кириллицы был подготовлен ученицей С. Малова кандидатом филологических наук Айшәм Шамиевой. В обсуждении уйгурского алфавита на основе кириллицы участвовали такие известные советские языковеды, как И.И. Мещанинов, С.Е. Малов, К.К. Юдахин, А.К. Боровков, Н.А. Баскаков, С. Кенесбаев (Кеңесбай, 1989: 6). Уйгурский язык был переведен на русскую графику по указу Верховного Совета Казахской ССР от 4 февраля 1947 г. (Кабиров, 1975: 250).

Тем самым советские уйгуры использовали латиницу в период с 1930 г. до 1947 г. В это время все периодические издания, книги и учебники на уйгурском языке издавались на латинской графике. С переходом на латиницу газета «Кәмбәғәлләр авази» в 1930 г. поменяла свое название на «Колхозчилар авази». Трудно сказать, какую на самом деле роль сыграла в культурной жизни советских уйгуров латинская графика. Однако именно она использовалась в очень сложный период советской истории, когда экономические и культурные достижения совпали со сталинскими репрессиями, унесшими жизни миллионов людей. По крайней мере с латиницей связаны достижения в области ликвидации безграмотности среди уйгурского населения. В 1937 г. уровень грамотности среди уйгурского населения Алма-Атинской области достиг 70-75\%. В тот год в 65 средних и неполных средних уйгурских школах области обучались 7447 учащихся, в том 
числе 1303 детей, обучавшихся в двух уйгурских школах г. Алма-Аты (Кулумбетов, 1989: 8). Учителей для уйгурских школ готовил педагогический техникум в г. Яркенде (ныне: Жаркент). Культурные достижения уйгуров Казахстана в 1930-е годы также были впечатляющими: достаточно сказать, что именно в те годы был создан Уйгурский театр музыкальной комедии. Создание Уйгурского района в местах компактного проживания в 1935 г. было призвано дальнейшему развитию уйгурской общины Казахстана.

После перехода уйгурского языка на латинский алфавит арабская графика не вышла из употребления в культурной жизни уйгуров Советского Союза. Она использовалась в специальных изданиях, адресованных читателям соседнего Синьцзяна. Как известно, в 1930-е годы Советский Союз помог прийти власти в Синьцзяне губернатора Шэн Ши-цая, проводившему просоветскую политику. Советское влияние достигло такого размера, что некоторые западные наблюдатели называли Синьцзян «полуколонией» СССР.

В Алма-Ате и Ташкенте в 1930-1940-е годы было напечатано огромное количество учебной, политической и художественной литературы на уйгурском языке синьцзянских читателей. Возможно, именно из-за отношений с Синьцзяном советское правительство не торопилось с переводом языка советских уйгуров на кириллицу. Примечательно, что решение о переводе уйгурского языка на кириллицу было принято в 1946 г., когда под давлением Советского Союза правительство Восточно-Туркестанской Республики (1944-1949 гг.) в трех округах (Или, Тарбагате, Алтае) пошло на свертывание военных действий против армии Гоминдана.

История «латинского пути» уйгурского языка в XX в. имеет еще одну страницу, связанную с латинизаций письменности уйгуров Синьцзяна. Так же, как в Советском Союзе, здесь сразу после образования КНР (1949 г.) реформа письменности началась с упрощения и приспособления арабской графики к особенностям уйгурского языка, первые шаги к которому начались уже в 1951 г. В мае 1954 г. правительство Синьцзяна утвердило новую арабскую графику уйгурского языка, которая была уже не слоговой, а фонетической. В ней были изъяты 8 арабских букв и введены 6 гласных. В годы советско-китайской дружбы в СУАР стала популярной идея перевода языков местных народов на кириллицу. Так, в августе 1956 г. на конференции по языкам и письменностям СУАР было принято решение о переводе уйгурского и казахс- кого языков на кириллицу. Однако уже в 1957 г. Институт языков национальных меньшинств рекомендовал переход языков на латинский алфавит. Предложенный в 1959 г. на Второй конференции по языкам национальных меньшинств СУАР проект латинского алфавита состоял из 33 букв, из которых 27 совпадали с латинской транскрипционной системой китайского языка. Хотя новый алфавит был утвержден официально правительством СУАР в октябре 1964 г., он был введен в употребление только в 1973 г. Уйгурский и казахский алфавиты на латинской основе в СУАР использовались в 1973-1976 гг. и были близки к латинской транскрипционной системе китайского языка (Наджип, 1960: 8). Вообще нужно отметить, что введение латиницы для малых народов в Китае было частью проекта латинизации китайской письменности. Использование уйгурского алфавита на латинской основе было прекращено в 1982 г., когда уйгурский язык вернулся к арабской графике.

\section{Заключение}

Таковы вкратце основные события и факты, связанные с переходом уйгурского языка на латинскую графику в Советском Союзе. Как и любая реформа письменности, латинизация осуществлялась в переломный период истории общества. Латинизация имела не только символическое значение как знамя культурной революции, но и стала эффективным инструментом в образовательной и просветительской политике страны Советов. Результатами развития советского общества в 1930-х годах стали полная индустриализация и коллективизация в экономике, ликвидация безграмотности населения и создание инфраструктуры культурных учреждений, достигших расцвета в поздний советский период.

В настоящее время Казахстан в своем поступательном движении возвращается к политике латинизации 1930-х годов, но уже на другом, качественно новом, витке исторического развития. Нынешняя латинизация письменности отвечает потребностям эпохи информационных технологий и глобализации, будет способствовать модернизации Казахстана и интеграции в мировое сообщество. Что касается нового латинского алфавита для языка уйгуров Казахстана, то он будет близок, если не идентичен, к новому казахскому алфавиту на основе латиницы, поскольку в фонетическом отношении эти языки очень близки, а используемая ныне уйгурская кириллица отличается от казахского алфавита только наличием в ней буквы «ж» с хвостиком. 


\section{Литература}

1 Brophy David. Uyghur Nation. Reform and Revolution on the Russian-China Frontier. - Cambridge MA - London Eng.: Harvard University Press, 2016. - 347 c.

2 Ғожәмбәрди Аблимит. Тил-имла мәсилисини ленинчә йешәйли // Яңливаштин туғулған уйғур хәлқи. - Алмута: Қазақстан, 1989. - С. 20-24.

3 Ерзин М. Становление и развитие уйгурской советской печати. - Алма-Ата: изд-во «Наука» КазССР, 1988. - 152 с.

4 Инқилабчи шәрқ. - №2 (май), 1929. - 39 с.

5 Кабиров М.Н. Очерки истории уйгуров советского Казахстана. - Алма-Ата: изд-во «Наука Казахской ССР», 1975. - 283 с.

6 Кеңесбай Смет. Уйғур имласи тоғрилиқ пикримиз // Янливаштин туғулған уйғур хәлқи. - Алмута: Қазақстан, 1989. - C. 24-29.

7 Кәмбәғәлләр авази. - №19 (266) от 10 апреля 1929 г. - С. 4.

8 Кәмбәғәлләр авази. - №30 (277) от 10 июня 1929 г. - С. 4.

9 Кулумбетов Узақбай. Қазақстандики уйғурларниң егилик вә мәдәнийәт мәйданидики утуқлири // Яңливаштин туғулған уйғур хәлқи. - Алмута: Қазақстан, 1989. - С. 6-10.

10 Малов С.Е. Памятники древнетюркской письменности. Тексты и исследования. - Москва-Ленинград: изд-во АН CCCP, 1951. - $452 \mathrm{c}$.

11 Муһәммәди Абдулһәй. Латинчилиқ йолидики биринчи кеңәш мәжилиси нәтижилири // Кәмбәғәлләр авази. - №30 (202) от 26 мая. - 1928. - С. 2-3.

12 Муһәммәди Абдулһәй. Қазақстан елипбәчилигиниң биринчи кәнипиринсийәси нәтижилири // Кәмбәғәлләр авази. №4 (251) от 21 января 1929. - С. 3.

13 Наджип Э.Н. Современный уйгурский язык. - М.: изд-во восточной литературы, 1960. - 134 с.

14 Садвакасов Г.С. Уйғур әдәбий тилиниң графикиси билән имласи // Сочинения. - Том. 2. - Алматы, 2009. - С. 284-340.

\section{References}

1 Brophy David. Uyghur Nation. Reform and Revolution on the Russian-China Frontier. - Cambridge MA - London Eng.: Harvard University Press, 2016. - 347 p.

2 Ghozhemberdi Ablimit. Til-imla mesilisini leninche yeshaili // Yanglivashtin tughulghan uyghur helqi. - Almuta: Qazaqstan, 1989. - S. 20-24.

3 Erzin M. Stanovleniye i razvitiye uyghurskoi sovetskoi pechati. - Alma-Ata: izd-vo 'Nauka' KazSSR, 1988. - 152 s.

4 Inqilabchi sherq. - №2 (May), 1929. - 39 s.

5 Kabirov M.N. Ocherki istorii uygurov sovetskogo Kazakhstana. - Alma-Ata: izd-vo ‘Nauka' KazSSR, 1975. - 283 s.

6 Kengesbay Smet. Uyghur imlasi toghriliq pikrimiz // Yanglivashtin tughulghan uyghur helqi. - Almuta: Qazaqstan, 1989. S. 24-29.

7 Kembegheller avazi. - №19 (266), 10 aprelya 1929 g. - S. 4.

8 Kembegheller avazi. - №30 (277), 10 iyunya 1929 g. - S. 4.

9 Kulumbetov Uzaqbay. Qazaqstandiki uyghurlarning egilik ve medeniyet meidanidiki utuqliri // Yanglivashtin tughulghan uyghur helqi. - Almuta: Qazaqstan, 1989. - S. 6-10.

10 Malov S.E. Pamitaniki drevnetyurkskoi pismennosti. Teksti i issledovaniya. - Moskva-Leningrad: izd-vo AN SSSR, 1951. $-452 \mathrm{~s}$.

11 Muhemmedi Abdulhei. Latinchiliq yolidiki birinchi kengash majilisi netichiliri // Kembegheller avazi. - №30 (202), 26 May. - 1928. - S. 2-3.

12 Muhemmedi Abdulhei. Qazaqstan elibechiligining birinchi kenipirinsiyasi netijiliri // Kembegheller avazi. - №4 (251), 21 yanvarya 1929. - S. 3 .

13 Nadjip E.N. Sovremenniy uygurskii yazik. - Moskva: izd-vo vostochnoi literaturi, 1960. - $134 \mathrm{~s}$.

14 Sadvakasov G.S. Uyghur edebiy tilining grafikisi bilen imlasi // Sochineniya. - Tom. 2. - Almaty, 2009. - S. 284-340. 